\title{
Impact of Job Situation on the Motivation of Insurance Companies Officers: A Developmental Perspective.
}

\author{
G.Balachandar, Dr.N.Panchanatham and Dr.K. Subramanian
}

\begin{abstract}
Motivation contributes immensely to the promotion of the efficiency of the officers of organizations. Insurance companies spend huge sum of money and, efforts for the satisfaction of their officers so as to make them more productive. Motivation results in commitment and dedication on the part of the officers in their duty. It results in the accomplishment of the organizational objectives at the appropriate time. Different factors are responsible for the motivation of the officers in the insurance company. But in this research work, researchers take job situation factor alone. The researchers study the impact of job situation factor on the motivation of insurance company officers. For this research work, private, government owned life Insurance and general insurance company officers are the respondents. Results of the Z-Tests highlight that officers of private and government insurance are of the same opinion about the motivational efforts taken by the organization. Results of correlation, Regression analysis infers that more than half of the total respondents are of the opinion that they are moderately influenced by the motivational factor.
\end{abstract}

Index Terms-Motivation, Job situation, pattern of working, Chance to learn, Use of abilities.

\section{INTRODUCTION}

Motivation is considered a vital factor influencing the behavior and activity of employees. Behind every action of a man, there has been a specific motive. Motivation as the way in which needs and aspirations of an individual direct and control his behavior, in organizational context engaged in work performance (Prasad 2009) [13]. It is based on an aim; when an employee is channelized, he reaches the aim quickly. In olden days, employees were influenced by monetary benefits. But now-a-days, they expect certain things in addition to money. According to (Tripathi 2001) [20] workers can be motivated by economic rewards, recognition, promotion, Job security, physical setup, training, and authority. If the above said factors are implemented rightly, employees will be satisfied with their job. In order to be successful, a company needs employees who act toward the goals of the organization and have strong desire to remain in the company (Molander, 1996) [8]. They are ready to do what ever task assigned to them. Employees do not sit idle in the work place and produce more output. It results in the satisfaction of external environment, and employee attrition rate gradually decreases. Image of the company can reach its benchmark in the market .Effective idea for motivation in the work place is simply to find out what works for our employees and provide it to them( Shobana Devi \& Sundara Pandian, 2010) [18]. If it works perfectly, especially in insurance industry; officers of insurance companies may be satisfied with the job. They may protect more public with suitable insurance plan.

\section{A. Job situation}

Job situation comprises place, environment, culture and climate in which an employee performs his duty in the company. Job situation characteristics are factors in the work environment which also affect motivation in the organization (Nirmal Singh, 2005) [10]. As like monetary reward, Job situation is also an inducer of an employee in the company. A challenging work environment and the support of top management are a very high motivator ( Horwitz et al, 2003 )[6]. Variables for the job situation are chance to learn, maximum use of abilities, and general pattern of working. Pattern of working refers to the total hours that a person works in his organization per day or per week. If the pattern of work is flexible in nature, it reduces absenteeism and employees turnover. Learning is the modification in the behavior of the employee towards the job. (Tripathi, 1997) [16] argues that "The main objective of human resource development is to create learning environment in the organization so that each member of the organization continuously learns and acquires new competencies". Employees have been told by the top officials how much output should be produced. Staff training is an indispensable strategy for motivating workers (Tella et al 2007) [20]. Employees must be told how much amount of output to be prepared and what are the ways and procedures to be followed in achieving the same. Employees expect their skills to be elicited completely during their tenure in the organization. It has two factors such as physical abilities, and intellectual abilities. When these two abilities are properly utilized by the organization, employees feel satisfied about their job. Employees are the valuable resources that may contribute in the several different ways to a company's activities, provided that the company gives them an appropriate chance (Morgan, 1997) [9]. It infers that the company should give freedom to the employees for learning.

\section{B. Meaningful Motivation}

Motivation is the word extracted from latin word " movere". It means " to activate" or " to influence". It is a field of psychological investigation concerned with certain types of phenomena and events (cofer \& Appley, 1980) [3].To retain the employees for the organization now - adays corporate realize the importance of employee motivation for the welfare of the organization.. Eunmi Chang suggests (2003) [4] that, motivating effect of money is well represented in the pay for performance 
system. Based on the performance of the employee, he should be fixed appropriate salary and incentives. It may be helpful to him to lead a peaceful life in the world. Managers are responsible for providing an environment conducive to performance (Harold Koontz \& Heinz Weihrich, 1995) [5]. Only top officials have to identify the needs of the employees. One of the factor influences the employee is chance to learn. Motivation is influenced by forward looking perceptions concerning the relationship between performance and rewards (Paul Hersey \& Kenneth H.Blanchard 19960 [ 8]. Recognition and reward are the major inducers for the officers to complete the duties at the right time.It creates positive image about the company and the job satisfaction of officers. An appropriate amount of job satisfaction contributes to the achievement of the organization (Ritu Lehal, 2000) [17] .It leads to retaining more employees and lesser absenteeism. The work can be made enjoyable and plesant if it is so designed that it allows the employees to satisfy ( Prasad , 1993) [ 10]. Pattern of work, pleasant working condition also induce the employee to achieve the target assigned to him.

\section{Profile about Insurance Industry}

Insurance is financial risk protection instrument. The main function of the insurance is to provide protection against the probable chances of loss (Bodla et al 2004) [1]. It not only increases the savings habit of the customers, but also protects the policyholders' family. It has sound history in India. In the year 1999, IRDA ACT was enacted by Government of India. By which private players are allowed to start their business in India along with foreign partners, with little restriction in capital of foreign players. As of now there are 26 life Insurance companies, 25 General Insurance companies in India. More over few more players wait to jump into the market by seeing the opportunity here .These new insurers come with innovative products, novel marketing ideas, and different distribution channels. Insurers are spending heavily on acquiring IT packages and work flow systems (Jawaharlal, 2004) [7]. Implementation of the every vital decision is by the insurance companies' top officials. They squeeze the brain consecutively to get victory. They have enormous physical and mental work. They are the forerunners of the insurance companies. They lead, manage, and administer the company in right direction. Continuously they have to update facts about the insurance industry, prospective customer's needs, demands and competitors' movement then only they can manage their organization rightly. Their contribution to the company is high. Success of the insurance company is behind the winning strategy taken by the officials.

\section{Need for the study}

Officers of the insurance companies are in the middle level, top level in the management. They are educated, skilled, experienced employees for the company. They must have more decision making skill, administrative skill, conceptual skill. They have to implement these skills in different proportion in different period. Work environment, Employee relationship must be smooth, then only they achieve the target fixed to them. They feel satisfaction about the company, job. This research work tries to examine the impact of job situation variables on motivation of officers of private, government insurance companies.

Objectives of the study:

1) To find out the Job situation variables and its influence on motivation of insurance company Officer.

2) To analyze the level of motivation of officers of private and government owned insurance company due to job situation variables.

3) To bring out measures to suggest both the insurance companies.

\section{Methodology}

This study used Analytical survey design. The target respondent for this research study were officers of both private, government owned insurance companies. These insurance companies spread various parts of Tirunelveli, Tuticorin, Kanyakumari districts of Tamilnadu in India. Researchers adopted the work motivation questionnaire of K.G.Agarwal. It has 26 questionnaires. A questionnaire consists of set of well-formulated questions to probe and obtain responses from respondents, (Paneerselvam, 2007) [14]. The questionnaire used in study was used to extract opinion from the respondent. The dimension Job situation is chosen for this research study. It has three variables such as chance to learn, use of abilities, and pattern of work. Questionnaires were distributed to the officers of insurance companies and got 80 from respondents.

\section{RESUlTS \& DisCUSSIONS}

Data are collected regarding the pattern of working of officers of both private, governments managed insurance companies. The mean value for the both the set of offices are almost same. It reveals that both the officers perform their task in the same manner. Further the opinion of the both sector employees are tested statistically by using ZTest by framing hypothesis.

TABLE -1: PATTERN OF WORKING AND MOTIVATION: RESULT OF Z -TEST

\begin{tabular}{|l|l|l|}
\hline & $\begin{array}{l}\text { Officers of Private } \\
\text { Insurers }\end{array}$ & $\begin{array}{l}\text { Officers } \\
\text { Government } \\
\text { Insurers }\end{array}$ \\
\hline Mean & 3.595744681 & 3.484848 \\
\hline Known Variance & 0.854764 & 1.507576 \\
\hline Observation & 47 & 33 \\
\hline $\begin{array}{l}\text { Hypothesized mean } \\
\text { Difference }\end{array}$ & 0 & \\
\hline $\mathrm{Z}$ & 0.438799564 \\
\hline $\mathrm{P}(\mathrm{Z}<=\mathrm{z})$ Two tail & 0.660806776 \\
\hline $\mathrm{Z}$ critical Two tail : & 1.959963985 \\
\end{tabular}

Ho: There are no difference between the officers private and government insurance companies with respect to Pattern of working.

The calculated value of $Z$ is 0.438799564 , but the tabular value of $Z$ is 1.959 . As the calculated value of $Z$ is less than the tabular value. It indicates that officers of both private, 
government insurance companies have the same level of opinion.

TABLE- 2 : USE OF ABILITIES AND MOTIVATION : RESULT OF Z - TEST
\begin{tabular}{|l|l|l|}
\hline & $\begin{array}{l}\text { Officers of } \\
\text { Private insurer }\end{array}$ & $\begin{array}{l}\text { Officers of } \\
\text { Government insurer }\end{array}$ \\
\hline Mean & 4.106383 & 3.8787 \\
\hline Known Variance & 1.097132 & 1.8598 \\
\hline Observation & 47 & 33 \\
\hline $\begin{array}{l}\text { Hypothesized Mean } \\
\text { Difference }\end{array}$ & 0 & \\
\hline$Z$ & 0.806172 \\
\hline $\mathrm{P}(\mathrm{Z}<=\mathrm{Z})$ Two tail & 0.420144 \\
\hline $\mathrm{Z}$ critical Two tail & 1.9599 \\
\hline
\end{tabular}

After having lot of experience in the company, employee attains the officer cadre in the insurance company. Their skills, knowledge about the job, talent are to be fully utilized the organization. Perhaps if it is used completely, they feel they are doing responsible duties in the company. Opinion is collected for the extent of skill, talent utilized by the officers of private, government insurance companies. The table shows that private and government insurance company officers are having similar perception about the utilization of skills, abilities, since the mean value for the both are same. For the purpose of explain it sharply, Z-test is statistically calculated with null hypothesis.

Ho : there are no vital difference between the officers of private and government insurance Companies in relation with utilization of ability.

The calculated value for $Z$ is 0.806172 and tabular value for the $\mathrm{Z}$ is 1.959964 . Since the calculated value of $\mathrm{Z}$-test is lesser than the tabular value, the null hypothesis is accepted. It interprets that the both officers government, private are of the same perception.

TABLE -3: CHANCE TO LEARN AND MOTIVATION: RESULT OF Z- TEST .
\begin{tabular}{|l|l|l|}
\hline & $\begin{array}{l}\text { Officers of } \\
\text { Private insurer }\end{array}$ & $\begin{array}{l}\text { Officers of } \\
\text { Government insurer }\end{array}$ \\
\hline Mean & 3.9787 & 4.0303 \\
\hline Known Variance & 0.977798 & 0.905303 \\
\hline Observation & 47 & 33 \\
\hline $\begin{array}{l}\text { Hypothesized Mean } \\
\text { Difference }\end{array}$ & 0 & \\
\hline $\mathrm{Z}$ & -0.23485 \\
\hline $\mathrm{P}(\mathrm{Z}<=\mathrm{Z})$ Two tail & .8143 \\
\hline $\mathrm{Z}$ critical Two tail & 1.959964 \\
\hline
\end{tabular}

Out standing and ever shine employees are created only through professional learning. Employees themselves feel, with out learning about the duties anything cannot take place. Continuous learning will enrich employee about duties, ethics in their organization. On the other side, to make the employee a knowledgeable person, Training program must be imparted frequently. It will thoroughly modify the behavior of the employee towards the organization. Responses are collected from the respondents and analysed, mean value is calculated. From the mean value it is clearly understood that both are having same opinion about chance to learn variable. To get further clearance, Z-test is used.

Ho : There are no difference between officers of private , government insurance company towards "Chance to learn".

The calculated value of $\mathrm{Z}$ is -0.23485 , Tabular value of $\mathrm{Z}$ is 1.959964. Calculated value is lesser than the tabular value. Null hypothesis is accepted. Hence it is concluded, both the officers are having similar opinion towards chance to learn.

Correlation and regression value for Job situation for the officers of Insurance companies:

Correlation is the statistical tool that we can use to describe the degree to which one variable is linearly related to another. Regression and correlation analysis will show us how to determine both the nature and the strength of a relationship between two variables (Richard \& David, 1986) [16]. In order to find out the influence of Job situation on motivation of private and government sector insurance officials, a correlation and regression analysis is used. The results of the analysis are presented as follows.

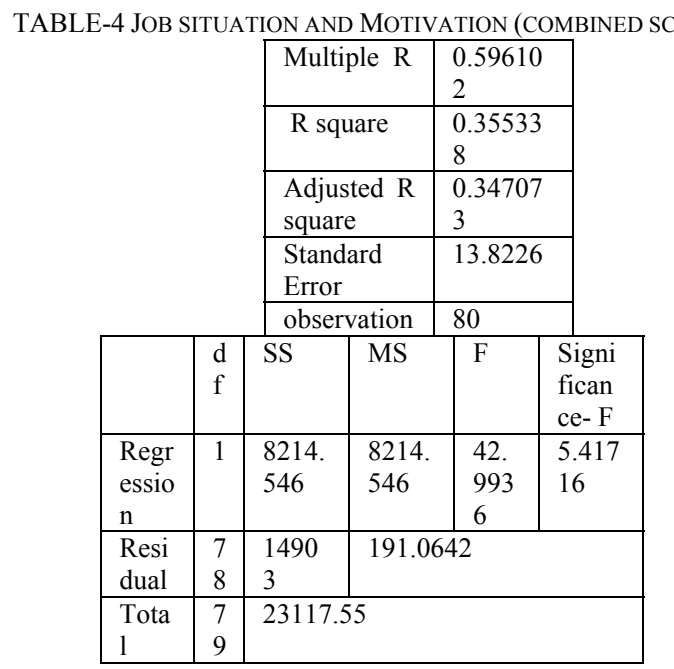

Data collected for job situation for both the private, government owned officers of insurance companies. Total score of the officers are compared with combined score of pattern of living, Chance to learn, use of abilities. The calculated correlation value for the impact of job situation on motivation is $59.61 \%$. It indicates job situation moderately influence motivation. Officers over all opinion about job situation infer that it moderately influences motivation. Efficiency of the officer only is elicited with the help environment of work place. Management should keep it their mind to satisfy the officer. General policy may be created in insurance companies in relation with work place situation. The policy that has been created should smooth the situation and everything in the organization.

\section{Findings \& SugGestions}

Both the private, government insurance company officials have same opinion about the satisfaction of pattern of working, chance to learn. However private sector insurance officials are offered comparatively better chances to learn about the insurance plans, special features, company's rules and regulations than the government insurance company officials. Separate training department with frequent on the job training, off the job training techniques are imparted to the officials might have motivated private insurance company officials a reasonable amount. Further correlation 
analysis indicates that the job situation is influencing the motivation of insurance officials to a reasonable extent. The final objective of this research work is to bring out measures to suggest both sector insurance companies. As the job situation variables are increasing the motivational level of insurance officials, both government and private insurance company management have to give adequate importance to these variables in order to boost up the motivational level. In government insurance companies due to job security, influence of union, officers do their duty at moderate speed. If they are provided good working environment, training, recognition, officers perform their task happily. In the case of private insurance company, officers are given higher salary, quick promotion, continuous training, do the work at the high speed. The main issue in the case of private insurance company is job insecurity. Right steps must be taken by the management to restraint this from the mind officers. If it does so, surely they may be highly motivated.

\section{MANAGERIAL IMPLICATION OF MOTIVATION}

Insurance plans are tangible products. It is being sold more with the help of the intermediaries like agents, Bancassurance, brokers and corporate agent. These intermediaries are trained to sell insurance plans to prospective customer only by the effort taken by the insurance company officers. Employees are the back bone of the organization ( Balachandar \& Panchanatham, 2010) [2]. Some crucial work such as underwriting, sales promotion, claims, Actuary, Investment of collected premium, Administration are the few of the tough duties done by the officers. Hence management must motivate them correctly for the satisfaction of the officers. The major outstanding factors which are responsible for the satisfaction of officers are company policy, Salary, working condition, pattern of working, and use of abilities, chance to learn. It results in smooth relation between the management and the officers. Permanent motivational practices followed by the company may increase of the reputation of the company in the mind of the agents, tie up banks, public. Finally it brings robust business to the insurance company.

\section{CONCLUSION}

Only in recent years Insurance companies top level management realize the necessity of employee motivation in the organization. Insurance management frames and designs innovative, different motivational methods, then implement it. The extent of involvement of the officers in their duty depends on the various motivational strategies followed by the management. Top management needs to concentrate on the motivation factors such as pattern of working, chance to learn and use of abilities. Mean value for the three motivational factors are almost similar for both the private and government owned insurance company officers. Jointly both the private, government insurance companies may further think about new motivational strategies for the officers for their satisfaction. It leads to low officer attrition rate, less absenteeism, better team work, and increase in the company image.

\section{REFERENCE}

[1] Bodla.B.S , Garg.M.G \& Singh.K.P (2004). Insurance Fundamentals, Environment and Procedures.Deep \& Deep Publications Pvt Ltd, New Delhi.

[2] Balachandar.G, Panchanatham.N (2010). Motivating insurance comapony employees@speed of the lightning. Life Insurance Today. Vol. 5, No. 12. PP 15- 18.

[3] Cofer.C.N. \& Appley.M.H (1980) . Motivation Theory and research..Wiley Eastern Limited, New Delhi

[4] Eunmi Chang. ( 2003). Compositer effects of motivation on work effort: case of Korean employees. Journal of world Business Vol:38. PP: 70-79

[5] Harold Koontz \& Heinz Weihrich (1990). Essentials of Management, McGraw- Hill International editions, New Delhi.

[6] Hortwitz.MF, Heng.T.C, Quazi.A.H ( 2003). Finders, keepers? Attracting,Motivating and retaining knowledge workers. Human Resource Management Journal, Vol.13, No.4, 2003, page 23-44.

[7] Jawaharlal.U ( 2004). Indian Insurance -market scenario. Insurance chronicle November,pp 17-20

[8] Molander.C. (1996). Human resources At work.Lund.ChartwellBratt.

[9] Morang.G (1997). Images of organization, Thousand oaks, Sage publications.

[10] Nirmal; Singh. (2005) Motivation. Theories and practical Applications.New Delhi. Deep \& Deep Publications pvt ltd.

[11] Paul Hersey \& Kenneth H.Blanchard ( 1996). Management of Organizational Behavior. Prentice Hall of India Private Limited, New Delhi.

[12] Prasad.L.M (1993). Organisational Behaviour. Sultan Chand \& Sons, New Delhi.

[13] Prasad.L.M (2009) Human Resource Mangement. Sultan Chand \& Sons, New Delhi

[14] Paneerselvam.R (2007). Research Methodolgy.Prentice Hall of India Private Limited, New Delhi

[15] Richard M.Steers \& Lyman W.Porter (19790. Motivation and Work behaviour. International student edition, New Delhi.

[16] Richard I, Levin \& David S.Rubin. (1986). Statistics for management. New Delhi: Prentice Hall of India Private Limited

[17] Ritu lehal. (2000). Organizational climate, Job satisfaction and managerial Effectiveness. New Delhi: Deep \& Deep Publications Pvt Ltd

[18] Shobana Devi.R \& Sundara Pandian. P , 2010. Building Motivation in Today's workplace. In Balachandar.G \& Panchanatham.N (Eds), Motivational Practices in Organisations: 206-210, , Deep \& Deep Publications private ltd, New Delhi

[19] Tella, Ayeni.C.O \& Popoola.S.O. (2007) Work motivation, Job satisfaction,organizational commitment of library personnel in Academic research librariesin oyo state. Library Philosophy and practice.

[20] Tripathi.P.C.(2002). Human Resource Development. New Delhi. Sultan chand \& sons. New Delhi

\section{BIOGRAPHY}

G.Balachandar. Place: Chidambaram, India. Date of birth: 8/11/1975. Educatioanl qualification: MBA- Marketing year -2000, Studied at VHNSN College, Tamilnadu. M.Phil- Entrepreneurship- 2001, Madurai Kamaraj University, Tamilnadu M.Com -year 2003, Annamalai University, India. Now working as Assistant Professor, Dept of Business Administration, Annamalai University, Tamilandu, Inida.

Book-1: Motivatioanl Practices in organizations ( New Delhi, Deep \& Deep Publications (PVT) Ltd Delhi, India, 2010).

Book-2: BE A MASTER (Chidambaram, Sree Publishers and printers, India, 2008)

Mr. G.Balachandar has published 7 articles in journals.

N.Panchanatham. Place: Chidambaram, India. Date of birth: 24/4/1963 Educatioanl qualification: MSc- Zoology year -1984, Studied at Annamalai University, MBA- Marketing ,year - 1987, Annamalai Univeristy, India.. Ph.D- 1995, Annamalai University, India. M.Com -year -1992, Madurai Kamaraj University, India. MICI- Counselling, Year -1999 , Minosetta, USA.

At present the second author is working is the Professor and Head, Dept of Business Administration, Annamalai University, Tamilandu, Inida

Book-1: Motivational Practices in organizations ( New Delhi, Deep \& Deep Publications (PVT) Ltd, New Delhi, India, 2010). 
Book-2: BE A MASTER (Chidambaram, Sree Publishers and printers, India, 2008)

Book-3 : Emerging Trends in Retail Management ( New Delhi, Delhi, India, Excel Books , 2008)

Dr.N. Panchanatham is an active member of Rotary club of Chidambaram. He has published more than 300 articles in various journals and edited books. Academic Visits to Countries such as U.S.A., U.K., Sweden, France, China, Singapore, Hong Kong, Thailand, Malaysia, Nepal, Israel, Mauritius, Cambodia, Vietnam, Cyprus, UAE. Indonesia and Srilanka.

Dr.K.Subramanian. . Place : Tirunelveli, India. Date of birth: 8/6/1964 Educatioanl qualification: B.Com- Costing ; year -1984, Studied at Madurai Kamaraj University, India.. M.Com - Business Systems; Year 1986, University of Madras, India. Ph.D -year 1993, Pondicherry University, India.

At present the third author is working as the Associate Professor, Dept of Commerce, Sri Paramakalyani college, Tirunelveli, Tamilandu, Inida

Journal-1: Yojana (1997). Discount Marketing strategies at $20^{\text {th }}$ century. Journal-2: Journal of Commerce (2009). Performance of Indian Mutual Funds

Dr.K.Subramanian is the Secretary of Lions club of Tenkasi. He has presented lot of papers in National and International level conferences, 